\title{
IDENTIFIKASI AGENS HAYATI POTENSIAL DARI TANAMAN KARUK (Piper sarmentosum)
}

\author{
Muhammad Firdaus Oktafiyanto ${ }^{1}{ }^{*}$, Eryna Elfasari Rangkuti ${ }^{2}$
}

${ }^{1,2}$ Fakultas Pertanian Universitas Ibnu Chaldun Jakarta

*Muhammadfirdausoktafiyanto@gmail.com

\begin{abstract}
Abstrak
Bakteri merupakan salah satu mikroba yang bermanfaat bagi tanaman karena mampu menghasilkan hormonpertumbuhan, serta memicu peningkatan ketahanan tanaman terhadap pathogen. Beberapa studi telah membuktikan isolasi bakteri yang berasal dari tanaman obat memiliki kemampuan untuk menekan pertumbuhan patogen. Penelitian ini bertujuan untuk mengisolasi bakteri dari tanaman karuk pada bagian rhizosfer, filosfer, filoflane serta bakteri endofit yang berada di dalam tanaman karuk. Penelitian dilakukan pada September 2015 sampai dengan Januari 2016 di Laboratorium Nematologi Tumbuhan Departemen Proteksi Tanaman, Institut Pertanian Bogor. Seleksi bakteri dilakukan dengan dua tahap yang pertama adalah metode keaman hayati dengan dua metode yaitu pengujian hemolisis pada media agar darah dan pengujian hipersensitif pada tanaman tembakau. Pengujian kedua adalah uji potensi bakteri calon agens hayati dilakukan dengan pengujian dual culture terhadap cendawan Fusariumoxysporum, kemudian dilanjutkan dengan uji pertumbuhan pada benih padi. Hasil isolasi bakteri calon agens hayati dari tanaman karuk menunjukan bahwa diperoleh 73 isolat bakteri yang terdiri dari bakteri yang berasal dari Rizosfer sebanyak 12, endofit sebanyak 19, Rizoplan sebanyak 20 bakteri, filoplan sebanyak 18 bakteri dan 4 isolat konsorsium. Hasil uji hemolisis pada media agar darah terdapat 58 bakteri yang positif dan tidak digunakan pada pengujian selanjutnya. Hasil uji hipersensitif pada tembakau terdapat 7 isolat bakteri yang lolos dan dilanjutkan ke pengujian berikutnya. Hasil uji pertumbuhan pada benih padi yang diberi bakteri isolat FP8 memiliki nilai tinggi tanaman terbaik sebesar $13.48 \mathrm{~cm}$ dan pada panjang akar terbaik pada perlakuan FP 16. Pengujian dual kultur perlakuan F8, F12, F16, RP13, RP14 mampu membuat pertumbuhan hifa cendawan Fusarium oxysporum menjadi abnormal jika dibandingkan dengan kontrolnya.
\end{abstract}

Kata kunci :Isolasi, Karuk, Hemolisis, hipersensitif, Hifa

\begin{abstract}
Bacteria is one of beneficial microbes for plants because they are able to produce growth hormones, and trigger an increase in plant resistance to pathogens. Several studies have proven isolation of bacteria from medical plants has the ability to suppress the growth of pathogens. This study aims to isolate bacteria from the karuk plant in the rhizosphere, phyllosphere, filoflane and endophytic bacteria in the karuk plant. The research was conducted from September 2015 to January 2016 at the Plant Nematology Laboratory of the Department of Plant Protection, Bogor Agricultural University. Bacterial selection was carried out in two stages, the first was a biosafety method with two methods, namely hemolysis testing on blood agar media and hypersensitivity testing on tobacco plants. The second test was a test for the potential of bacteria as a candidate for biological agents, carried out by dual culture testing on the fungus Fusarium oxysporum, then continued with a growth test on rice seeds. The results of the isolation of potential biological agents from the karuk plant showed that there were 73 bacterial isolates consisting of 12 bacteria from the rhizosphere, 19 endophytes, 20 rhizoplan bacteria, 18 bacteria filoplans and 4 consortium isolates. The results of the hemolysis test on blood agar media contained 58 positive bacteria and were not used for further testing. The results of the hypersensitivity test on tobacco contained 7 bacterial isolates that passed and were continued to the next test. The results of the growth test on rice seeds that were given FP8 isolate bacteria had the best plant height value of $13.48 \mathrm{~cm}$ and the best root length in FP 16 treatment. abnormal when compared to the control.
\end{abstract}

Keyword: Isolation, Karuk, hemolysishypersensitive, hyphae 


\section{Pendahuluan}

Indonesia adalah satu pusat agrobiodiversitas dunia karena memiliki keragaman biodeversitas yang tinggi. Tercatat bahwa Indonesia memiliki 1259 spesies tumbuhan yang dimanfaatkan kayunya, 984 spesies tumbuhan pangan yaitu gabungan dari sayur, buah, biji dan umbi, 520 spesies penghasil minyak, dammar, pewarna dan senyawa kimia lain, serta 6186 spesies yang dapat di manfaatkan sebagai tanaman obat (Whitemore 1985 dalam Kusmana \& Hikmat 2015; Kartawinata. 2010). Kekayaan biodiversitas yang dimiliki Indonesia belum dapat dimanfaatkan secara maksimal. Salah satu cara pemanfaatan kekayaan biodiversitas yang dimiliki Indonesia dengan melakukan pencarian agens hayati potensial yang mampu memacu pertumbuhan tanaman dan melindunginya dari serangan penyakit.

Soesanto (2008), menyebutkan bahwa agens pengendali hayati merupakan organisme hidup yang dapat digunakan untuk mengendalikan penyakit, yang terjadi akibat adanya metabolisme sekunder baik berupa antibiotika, toksin, enzim atau hormone. Penggunaan agens hayati selain dapat meningkatkan pertumbuhan tanaman serta menangkal dari serangan penyakit juga mampu mengurangi masalah yang ditimbulkan dari penggunaan pupuk dan pestisida berbahan kimia sintetik secara berlebih yang dapat mengganggu kestabilan lingkungan ekosistem tanaman.

Agens hayati ternyata dapat ditemukan dari disekitar tanaman, menurut beberapa peneliti sumber agens antagonis yang banyak dilaporkan antara lain berasal dari rhizosfer (Whipps 2001), filosfer (Andrews 1992), filoplane (Blakeman dan Fokkema 1982), dan endofit (Petrini et al. 1993). Penelitian ini menggunakan tanaman Karuk sebagai sumber pengambilan agens hayati.

Tanaman karuk merupakan salah satu tanaman obat yang dapat tumbuh baik diberbagai kondisi iklim baik tropis maupun subtropik. Penelitian terdahulu menyatakan bakteri yang diisolasi dari tanaman obat memiliki potensi menekan pertumbuhan pathogen (Desriani et al. 2014 ) Hingga saat ini tanaman karuk belum pernah diteliti sebagai sumber agens hayati, sehingga perlu dilakukan eksplorasi agens hayati dari tanaman karuk untuk melihat potensinya sebagai agens pengendali hayati. Penelitian ini bertujuan untuk mengisolasi bakteri dari tanaman karuk pada bagian rhizosfer, filosfer, filoplan serta bakteri endofit yang berada di dalam tanaman karuk dan menguji patogenesitas bakteri yang diperoleh dan menguji kemampuan bakteri calon agens hayati dalam memacu pertumbuhan tanaman dan kemampuannya menghambat pertumbuhan cendawan patogen Fusarium oxysporum secara invitro.

\section{Bahan dan Metode}

\section{Waktu dan Tempat Penelitian}

Penelitian ini dilaksanakan di Laboratorium Nematologi Tumbuhan Departemen Proteksi Tanaman, Institut Pertanian Bogor dari September 2015 sampai dengan Januari 2016. Bahan yang digunakan adalah sampel pertanaman karuk (tanah bagian rhizosfer, filoplane dan endofit), media TSA 20\%, 100\%, media PDA, $\mathrm{KOH} 3 \%$, benih padi varietas Mekongga, tanaman tembakau varietas Kemloko, dan isolat cendawan Fusarium sp. Alat yang digunakan adalah mortal, cawan petri, drill glass, erlenmeyer, tabung reaksi, gunting, gelas objek, shaker, suntikan, dan laminar air flow.

\section{Isolasi Agens Hayati pada Tanaman Karuk Bagian Rhizosfer dan Filoplane}

Tanah pada daerah perakaran (rhizosfer) diambil dan ditimbang $10 \mathrm{~g}$, kemudian dimasukkan ke dalam erlenmeyer dan ditambahkan akuades sebanyak 100 $\mathrm{mL}$. Selanjutnya disuspensikan dengan cara di shake pada kecepatan $100 \mathrm{rpm}$ selama 1 jam. Suspensi diambil $1 \mathrm{~mL}$ dan dilakukan pengenceran sampai $10^{-3}$, kemudian $0,1 \mathrm{~mL}$ suspensi di plating pada media TSA $20 \%$.

Untuk isolasi mikroba pada bagian filoplane (permukaan daun) dilakukan dengan cara menimbang 1 gr daun, kemudian di tambahkan $10 \mathrm{~mL}$ akuades steril dan di shake selama 30 menit. Selanjutnya dilakukan pengenceran sampai $10^{-2}$. Hasil pengenceran kemudian diplating pada media TSA $20 \%$.

Untuk isolasi bakteri endofit, masing-masing bagian akar, batang dan daun tanaman digerus, kemudian disuspensikan pada akuades steril dan dilakukan pengenceran sampai $10^{-3}$, dan diambil sebanyak $1 \mathrm{~mL}$ untuk diplating pada media TSA $20 \%$, setelah itu diinkubasi pada suhu ruang. Uji kesterilan bagian tanaman yang diisolasi dilakukan dengan cara menggoreskan masing-masing potongan akar, batang dan daun mentimun pada media TSA untuk bakteri endofit (Hallmann et al. 1997).

\section{Pengujian Keamanan Hayati Calon Agens Hayati Uji Hemolisis}

Pengujian dilakukan pada media agar darah. Media agar darah dibuat dengan cara membuat media TSA $100 \%$ dan disterilisasi menggunakan autoklaf dengan suhu $121^{\circ} \mathrm{C}$ selama 15 menit. Media TSA yang telah disterilisasi, didinginkan hingga mencapai suhu $45-50^{\circ} \mathrm{C}$, kemudian media dicampur dengan darah kambing dengan konsentrasi 5\% yang telah disaring menggunakan millipore $0.22 \mu \mathrm{m}$. bakteri ditumbuhkan 
pada media agar darah dan selanjutnya diinkubasi selama 18-24 jam pada suhu $37{ }^{\circ} \mathrm{C}$. Adanya aktivitas hemolisis ditandai dengan adanya zona hemolisis pada plat agar darah. bakteri yang menghasilkan toksin alfahemolisis akan membentuk zona bening disekitar koloni, yang menghasilkan toksin beta-hemolisis akan membentuk zona agak gelap disekitar koloni, dan yang menghasilkan gamma-hemolisis tidak membentuk zona bening disekitar koloni dan tidak merubah warna media. bakteri endofit yang memproduksi kombinasi toksin alfa-hemolisis dan beta-hemolisis akan tampak zona gelap dan bening disekitar koloni(Oktavia Salasia et al. 2004). Bakteri yang menunjukkan toksin alfa, beta, dan alfa-beta hemolisis tidak digunakan dalam pengujian selanjutnya karena berpotensi membahayakan kesehatan manusia(Khusnan et al. 2008).

\section{Uji Hipersensitif}

Uji patogenesis bakteri dilakukan dengan cara satu ose isolat bakteri yang diuji diinokulasikan pada 3 $\mathrm{mL}$ media NB cair di dalam tabung reaksi. Kemudian shaker dengan kecepatan $80 \mathrm{rpm}$ selama 24 jam. Suspensi bakteri diambil menggunakan jarum suntik steril yang telah dilepas bagian jarumnya. Injeksikan suspensi bakteri dari bagian bawah daun tembakau. Bagian yang diinjeksi suspensi bakteri diberi label. Hasil injeksi diamati setelah 24-48 jam. Reaksi positif yang berarti bakteri tersebut bersifat patogenik ditunjukkan dengan adanya bercak nekrosis pada bagian yang diinokulasikan dengan suspensi bakteri, sebaliknya reaksi negatif terjadi bila warna daun tetap hijau (Klement et al. 1990).

\section{Pengujian Antibiosis}

Uji antibiosis isolat bakteri rhizosfer, rhizoplane, dan endofit yang diperoleh dilakukan terhadap cendawan patogen Fusarium oxysporum dengan metode dual culture. Cendawan patogen diambil menggunakan cork borer kemudian diletakkan pada media PDA tengah cawan. Setelah itu masing-masing isolat bakteri calon agens hayati digores pada bagian sisi cawan dan diinkubasi selama 5 hari. Pengamatan dilakukan dengan melihat ada atau tidaknya zona hambat yang terbentuk antara inokulum cendawan dan isolat agens hayati.

\section{Pengujian Bakteri terhadap Pertumbuhan Tanaman}

Uji pertumbuhan dilakukan terhadap benih padi. Bakteri yang berumur 24-48 jam disuspensikan padaakuades steril, kemudian masing-masing benih padi yang telah disterilisasi permukaan direndam dalam suspensi bakteri tersebut selama 24 jam. Setelah direndam, masing-masing benih kemudian ditanam pada media tanah steril ditray. Masing-masing perlakuan diulang sebanyak 5 kali.(Vrbničanin et al. 2011).

\section{Hasil dan Pembahasan}

\section{Isolasi Calon Agens Hayati}

Hasil isolasi bakteri dari taman karuk diperoleh 73 isolat bakteri yang terdiri dari bakteri yang berasal dari Rizosfer sebanyak 12, endofit sebanyak 19, Rizoplan sebanyak 20 bakteri, filoplan sebanyak 18 bakteri dan 4 isolat konsorsium. Setelah berhasil diisolasi bakteri tersebut dikarakterisasi berdasarkan sifat morfologinya mulai dari bentuk tekstur hingga warna disajikan dalam tabel berikut.

Pengamatan morfologi dilakukan dengan mengamati sembilan ciri-ciri dari bakteri yang diperoleh mulai dari bentuk, tepian, elvasi (ketinggian), ukuran, tekstur, penampilan, pigmen, dan optical property/sifat tembus cahaya (ATCC, 2015). Pengamatan bentuk dilakukan dengan mengamati bentuk koloni bakteri yaitu bulat (circular), seperti akar / menyebar (rhizoid), tidak beraturan (irregular), berserabut (filamentous), serta lonjong (spindle).. Pengamatan tepian koloni yaitu tepian rata (entire), tepi bergelombang (undulate), berlekuk (lobate), melengkung (curled), bergerigi (rhizoid), tepi seperti benang-benang tidak beraturan (filamentous). Pengamatan ketinggian koloni yaitu dengan ketinggian nyaris rata dengan medium (flat), terangkat/ketinggian nyata terlihat, namun rata pada seluruh permukaan (raised), cembung /permukaan melengkung (convex), berbentuk bantal (pulvinate), serta cembung di tengah (umbonate). Ukuran berbentuk seperti titik (punctiform), kecil (small), sedang (moderate), dan besar (large). Penampilan menggambarkan jika koloni mengkilap (glistening), kusam (dull). Properti Tekstur. Koloni seperti kasar (rough) halus (smooth). Pigmentasi atau warna koloni, dan pengamatan. Optical property menggambarkan sifat bakteri terhadap cahaya yaitu tidak tembus cahaya (opacity) terlihat buram (opaque), atau tidak tembus cahaya, (translucent), dan transparan. 
Tabel 1. Identifikasi morfologi bakteri Rizosfer

\begin{tabular}{|c|c|c|c|c|c|c|c|c|}
\hline Kode & Bentuk & Tepi & Elevasi & Ukuran & Tekstur & Penampilan & Pigmen & Optical property \\
\hline R1 & Irregular & Curled & Raised & Large & Smooth & Dull & White & Opaque \\
\hline $\mathrm{R} 2$ & Irregular & Curled & Raised & Large & Smooth & Dull & White & Opaque \\
\hline R3 & Irregular & Curled & Raised & Large & Smooth & Dull & White & Opaque \\
\hline $\mathrm{R} 4$ & Irregular & Curled & Raised & Large & Smooth & Dull & White & Opaque \\
\hline R5 & Irregular & Curled & Raised & Large & Smooth & Dull & White & Opaque \\
\hline R6 & Irregular & Curled & Raised & Large & Smooth & Dull & White & Opaque \\
\hline R7 & Irregular & Curled & Raised & Large & Smooth & Dull & White & Opaque \\
\hline $\mathrm{R} 8$ & Irregular & Curled & Raised & Large & Smooth & Dull & White & Opaque \\
\hline R9 & Irregular & Curled & Raised & Large & Smooth & Dull & White & Opaque \\
\hline $\mathrm{R} 10$ & Irregular & Curled & Raised & Large & Smooth & Dull & White & Opaque \\
\hline R11 & Irregular & Curled & Raised & Large & Smooth & Dull & White & Opaque \\
\hline $\mathrm{R} 12$ & Irregular & Curled & Raised & Large & Smooth & Dull & White & Opaque \\
\hline
\end{tabular}

Tabel 2. Identifikasi Morfologi Bakteri Rizoplan

\begin{tabular}{|c|c|c|c|c|c|c|c|c|}
\hline Kode & Bentuk & Tepi & Elevasi & Ukuran & Tekstur & Penampilan & Pigmen & Optical property \\
\hline RP1 & Irregular & Undulate & Raised & Large & Smooth & Dull & White & Opaque \\
\hline RP2 & Circular & Entire & Raised & Small & Smooth & Glistening & White & Opaque \\
\hline RP3 & Irregular & Lobate & Raised & Moderate & Smooth & Dull & Cream & Opaque \\
\hline RP4 & Irregular & Undulate & Raised & Large & Smooth & Dull & White & Opaque \\
\hline RP5 & Circular & Entire & Raised & Small & Smooth & Glistening & White & Opaque \\
\hline RP6 & Irregular & Undulate & Raised & Moderate & Smooth & Dull & Cream & Opaque \\
\hline RP7 & Irregular & Undulate & Raised & Large & Smooth & Dull & White & Opaque \\
\hline RP8 & Irregular & Undulate & Raised & Large & Smooth & Dull & White & Opaque \\
\hline RP9 & Circural & Entire & Convex & Small & Smooth & Glistening & Yellow & Translucent \\
\hline RP10 & Irregular & Undulate & Raised & Large & Smooth & Dull & White & Opaque \\
\hline RP12 & Circular & Entire & Convex & Punctiform & Smooth & Glistening & Yellow & Translucent \\
\hline RP13 & Circular & Entire & Convex & Small & Smooth & Glistening & Yellow & Translucent \\
\hline RP14 & Irregular & Undulate & Raised & Large & Smooth & Dull & Cream & Opaque \\
\hline RP15 & Circular & Entire & Convex & Small & Smooth & Glistening & Orange & Translucent \\
\hline RP16 & Circular & Entire & Convex & Small & Smooth & Glistening & Yellow & Translucent \\
\hline RP17 & Irregular & Undulate & Raised & Large & Smooth & Dull & White & Opaque \\
\hline RP18 & Circular & Entire & Raised & Large & Smooth & Glistening & White & Opaque \\
\hline RP19 & Irregular & Undulate & Raised & Large & Smooth & Dull & White & Opaque \\
\hline RP20 & Irregular & Undulate & Raised & Large & Smooth & Dull & Cream & Opaque \\
\hline
\end{tabular}


Tabel 3. Identifikasi Morfologi Bakteri Filoplan

\begin{tabular}{|c|c|c|c|c|c|c|c|c|}
\hline Kode & bentuk & Tepi & Elevasi & Ukuran & tekstur & penampilan & pigmen & Optical property \\
\hline $\mathrm{F} 1$ & Irregular & Undulate & Raised & Large & Smooth & Dull & White & Opaque \\
\hline $\mathrm{F} 2$ & Irregular & Curled & Raised & Large & Smooth & Dull & Cream & Opaque \\
\hline F3 & Irregular & Curled & Raised & Large & Smooth & Dull & Cream & Opaque \\
\hline F4 & Irregular & Undulate & Raised & Large & Smooth & Dull & White & Opaque \\
\hline F5 & Irregular & Undulate & Raised & Large & Smooth & Dull & White & Opaque \\
\hline F6 & Irregular & Undulate & Raised & Large & Smooth & Dull & White & Opaque \\
\hline F7 & Irregular & Curled & Raised & Large & Smooth & Dull & Cream & Opaque \\
\hline F8 & Circular & Entire & Convex & Punctiform & Smooth & Glistening & Orange & Transparant \\
\hline F9 & Circular & Entire & Convex & Punctiform & Smooth & Glistening & Yellow & Translucent \\
\hline F10 & Irregular & Undulate & Raised & Large & Smooth & Dull & White & Opaque \\
\hline F11 & Irregular & Undulate & Raised & Large & Smooth & Dull & White & Translucent \\
\hline $\mathrm{F} 12$ & Circular & Entire & Convex & Punctiform & Smooth & Glistening & Yellow & Translucent \\
\hline F13 & Irregular & Undulate & Raised & Large & Smooth & Dull & White & Opaque \\
\hline F14 & Irregular & Undulate & Raised & Large & Smooth & Dull & White & Opaque \\
\hline F15 & Irregular & Curled & Raised & Large & Smooth & Dull & Cream & Opaque \\
\hline F16 & Circular & Entire & Convex & Punctiform & Smooth & Glistening & Yellow & Translucent \\
\hline F17 & Irregular & Undulate & Raised & Large & Smooth & Dull & White & Opaque \\
\hline F18 & Irregular & Lobate & Raised & Large & Smooth & Dull & Cream & Opaque \\
\hline
\end{tabular}

Tabel 4. Identifikasi Morfologi Bakteri Endofit

\begin{tabular}{|c|c|c|c|c|c|c|c|c|}
\hline Kode & Bentuk & Tepi & Elevasi & Ukuran & Tekstur & Penampilan & Pigmen & Optical property \\
\hline E1 & Irregular & Curled & Raised & Large & Smooth & Dull & White & Opaque \\
\hline E2 & Irregular & Curled & Raised & Large & Smooth & Dull & White & Opaque \\
\hline E3 & Irregular & Curled & Raised & Large & Smooth & Dull & White & Opaque \\
\hline E4 & Filamentous & Rhizoid & Flat & Large & Smooth & Dull & White & Opaque \\
\hline E5 & Irregular & Curled & Raised & Large & Smooth & Dull & White & Opaque \\
\hline E6 & Irregular & Curled & Raised & Large & Smooth & Dull & White & Opaque \\
\hline E7 & Irregular & Undulate & Raised & Large & Smooth & Dull & White & Opaque \\
\hline E8 & Circular & Entire & Raised & Moderate & Smooth & Dull & White & Translucent \\
\hline E9 & Filamentous & Rhizoid & Flat & Large & Smooth & Dull & White & Opaque \\
\hline E10 & Irregular & Curled & Raised & Large & Smooth & Dull & White & Opaque \\
\hline E11 & Filamentous & Rhizoid & Flat & Large & Smooth & Dull & White & Opaque \\
\hline E12 & Irregular & Undulate & Raised & Moderate & Smooth & Dull & White & Opaque \\
\hline E13 & Irregular & Undulate & Raised & Moderate & Smooth & Dull & White & Opaque \\
\hline E14 & Irregular & Undulate & Raised & Moderate & Smooth & Dull & White & Opaque \\
\hline E15 & Irregular & Undulate & Convex & Moderate & Smooth & Dull & White & Opaque \\
\hline E16 & Irregular & Curled & Raised & Large & Smooth & Dull & White & Opaque \\
\hline E17 & Irregular & Curled & Raised & Large & Smooth & Dull & White & Opaque \\
\hline E18 & Circular & Undulate & Convex & Moderate & Smooth & Dull & White & Opaque \\
\hline E19 & Circular & Undulate & Convex & Moderate & Smooth & Dull & White & Opaque \\
\hline
\end{tabular}


Hasil pengamatan pada bentuk koloni bakteri yang berhasil diperoleh dari bagian endofit, filoplan, rizosfer, dan rizoplan bentuk bakteri yang muncul adalah irregular, circular, dan filamentous.Pengamatantepian koloni bakteri yang ditemukan cukup beragam bentuk tepian seperti undulate, curled, rhizoid, lobate, dan entire. Pengamatan pada ketinggian/elevasi koloni bakteri menunjukan bentuk raised mendominasi tipe elevasi bakteri pada semua bagian, kemudian diikuti bentuk convex, dan flat. Hasil pengamatan ukuran koloni bakteri terdapat bakteri yang berbentuk seperti titik (punctiform), kecil (small), sedang (moderate), dan besar (large). Pengamatan tekstur koloni bakteri dari semua bagian memiliki tekstur yang lembut (smooth).

Pengamatan pada penampilan koloni bakteri endofit dan rizosfer, menunjukan semua koloni bakteri memiliki penampilan yang kusam $(d u l l)$. Pengamatan pada bakteri filoplan dan rizoplan didominasi penampilan kusam (dull), serta ada yang memiliki penampilan yang mengkilap (glistening). Pengamatan pada pigmen koloni bakteri didominasi oleh warna putih yang muncul pada semua koloni bakteri endofit dan rizosfer, sedangkan pada koloni rizoplan memiliki warna lebih beragam seperti putih, krem, kuning, dan oranye. Pengamatan. Optical property koloni menunjukan bakteri didominasi oleh opaque, diikuti translucent dan transparan.

\section{Pengujian Agar Darah.}

Hasil pengujian aktifitas hemolisis terdapat 58 isolat bakteri yang positif uji hemolisis ditunjukan dengan terbentuknya zona bening pada Gambar 1 . $\mathrm{Ke}-58$ isolat tersebut dapat mendegradasi komponen media hemolisis menjadi bening yang menunjukan adanya aktifitas $\alpha$ hemolisin dan $\beta$ hemolisin ke dua toksin tersebut sangat berbahaya karena dapat mendegradasi komponen sel darah manusia (Duncan et al.2007;Nataliya et al. 2006)

Hasil pengujian ini terdapat 15 isolat bakteri yang dilanjutkan ke pengujian berikutnya dan dinyatakan aman rhizoplan sebanyak 4 yaitu RP2, RP9, RP13, RP14, RP20. Bakteri filoplan sebanyak 3 yaitu FP8, FP9, FP12, FP16, bakteri endofit sebanyak 6 bakteri yaitu E7, E8, E15, E18, E19. Bakteri tersebut selanjutnya dilanjutkan ke pengujian hipersensitif.

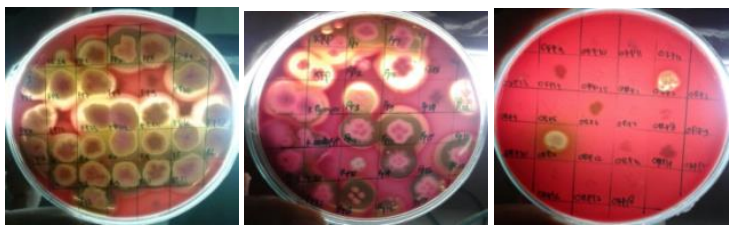

Gambar 1 Hasil uji hemolisis bakteri

\section{Pengujian Hipersensitif}

Hasil pengujian menunjukkan terdapat 8 bakteri yang bersifat patogen pada tanaman sehingga dari 15 isolat, 7 isolat bakteri saja yang dapat dilanjutkan kepengujian berikutnya. Berikut adalah bakteri yang lolos dalam pengujian hipersensitif, bakteri rhizoplan sebanyak 3 yaitu RP13, RP 14, RP20. Bakteri filoplan sebanyak 4 yaitu FP8, FP9, FP12, FP16, Bakteri tersebut selanjtutnya dilanjutkan ke pengujian growing on test dan pengujian dual culture.

Reaksi hipersensitif merupakan program kematian sel yang cepat dan terlokalisasi. Reaksi ini muncul pada tanaman yang terinfeksi saat pengenalan patogen dan bersamaan dengan itu, merupakan usaha untuk menghambat pertumbuhan patogen. Induksi reaksi hipersensitif dan patogenisitas dipengaruhi oleh gen hrp yang umum ditemukan pada bakteri Gram negatif patogen tanaman (Wahyudi et al. 2011). Reaksi tersebut ditandai dengan timbulnya gejala nekrotik sebagai akibat sel-sel di sekitar serangan patogen mati secara cepat, sehingga perkembangan patogen tersebut ke jaringan tanaman yang lain terhambat. Gejala nekrotik akan timbul $8-24$ jam setelah inokulasi. Isolat yang menunjukan reaksi hipersensitif tidak dilanjutkan pada pengujian berikutnya.

\section{Pengujian Growing on test Pada benih padi.}

Pengujian ini merupakan pengujian lanjutan untuk mencari potensi bakteri calon agens hayati. Pengujian ini dilakukan dengan merendam benih tanaman padi dalam suspensi bakteri calon agens hayati selama 24 jam selanjutnya benih ditanam pada tray setelah 2 minggu diamati tinggi tanaman dan panjang akar dar tanaman uji tersebut. Hasil pengujian menunjukan hasil berikut (Tabel 5).

Tabel 5. Pengujian growing on test pada benih padi

\begin{tabular}{|c|c|c|c|}
\hline No & Perlakuan & $\begin{array}{c}\text { Tinggi tanaman } \\
(\mathrm{cm})\end{array}$ & $\begin{array}{c}\text { Panjang akar } \\
(\mathrm{cm})\end{array}$ \\
\hline 1 & Kontrol NB & 9.1 & 7.4 \\
\hline 2 & RP 13 & 11.52 & 6.66 \\
\hline 3 & RP 14 & 12.58 & 6.92 \\
\hline 4 & RP20 & 12.1 & 8.18 \\
\hline 5 & FP8 & $13.48^{*}$ & 7.9 \\
\hline 6 & FP9 & 12.2 & 8.64 \\
\hline 7 & FP12 & 12.26 & 7.02 \\
\hline 8 & FP16 & 12.78 & $8.7^{*}$ \\
\hline 9 & KONTROL AIR & 11.08 & 6.32 \\
\hline
\end{tabular}

Keterangan : $\mathrm{RP}=$ Rhizoplane, $\mathrm{FP}=$ Filoplane 
Bakteri yang telah lolos pengujian keamanan hayati selanjutnya diuji pada benih untuk melihat potensinya sebagai pemacu pertumbuhan. Hasil pengujian menunjukkan bahwa perendaman bakteri dapat memacu pertumbuhan dari tanaman jika dibandingkan dengan kontrolnya. Perlakuan FP8 menunjukkan nilai tinggi tanaman yang tertinggi jika dibandingkan dengan perlakuan lain yaitu sebesar $13.48 \mathrm{~cm}$ dan yang terendah adalah perlakuan kontrolnya dengan $9.1 \mathrm{~cm}$, sementara untuk panjang akar perlakuan FP 16 memiliki nilai tertinggi yaitu 8.7 $\mathrm{cm}$ dan panjang akar terrendah dimiliki oleh perlakuan kontrol air dengan $6.32 \mathrm{~cm}$. Peningkatan tinggi tanaman dan panjang akar tanaman uji menunjukan kemampuan bakteri calon agens hayati sebagai agens pemacu pertumbuhan, karena pada tanaman yang diberi perlakuan dengan bakteri diduga dapat terjadi karena bakteri berperan dalam pengikatan nitrogen, peningkatan aktivitas fotosintesis, dan peningkatan hormon pertumbuhan seperti indole acetic acid (IAA) (Lopez et al 2012; Duangpaeng et al. 2012). Penelitian sebelumnya telah membuktian bahwa aplikasi bakteri yang diisolasi dari tanaman kaktus Mammillaria fraileana mampu meningkatkan pertumbuhan tanaman. Mekanisme yang terjadi adalah bakteri berperan dalam memobilisasi elemen-elemen hara sehingga mampu meningkatkan aktivitas fotosintesis dan akumulasi biomasa (Lopez et al. 2012). Hasil pengujian di atas menunjukan bahwa bakteri-bakteri yang berasal dari daerah filoplan ternyata mampu meningkatkan pertumbuhan baik akar dan tinggi dari tanaman lebih baik dari bakteri yang diisolasi dari daerah perakaran dan endofit. Pengunaan bakteri filoplan sebagai PGPR saat ini belm banyak dilakukan dan diteliti karena sampai saat ini bateri-bakteri PGPR banyak berasal dari daerah perakaran tapi tidak menutup kemungkinan bahwa bakteri yang mengkolonisasi daerah bagian atas tanaman dapat berfungsi sebagai bakteri PGPR, selain itu bakteri yang diisolasi dari bagian atas tanaman memiliki ketahanan yang relatif lebih tinggi dibandingkan bakteri tanah terhadap perubahan suhu yang ekstrim, bakteri tersebut juga dapat memperbanyak diri dan mengkolonisasi didaerah yang sedikit nutrisi dibandingkan bakteri daerah perakaran yang ketersediaan nutrisi melimpah (Kishore et al 2005)

Hasil di atas juga menunjukan bahwa bakteri yang berfungsi sebagai pemacu pertumbuhan ternyata mampu untuk menekan pertumbuhan cendawan patogen. Hal itu terlihat pada perlakuan FP 8 dan FP 16 yang mampu menekan pertumbuhan cendawan patogen. Hal tersebut sesuai dengan penelitian Yulia et al (2008) yang menyatakan bakteri asal daerah filoplan mampu meningkatkan pertumbuhan tanaman dan menekan pertumbuhan patogen hingga angka $70.85 \%$ artinya bakteri tersebut memiliki fungsi ganda selain sebagai pemacu pertumbuhan ternyata penggunaan bakteri filoplan mampu menekan pertumbuhan dari patogen tanaman.

\section{Pengujian Dual Culture}

Pengujian selanjutnya yang dilakukan pada percobaan kali ini adalah pengujian kultur ganda terhadap cendawan patogen Fusarium oxysporum. Penggunaan cendawan ini sebagai cendawan uji karena Fusarium oxysporum merupakan patogen yang sangat merugikan bagi tanaman budidaya di Indonesia terutama tanaman hortikultura (Soesanto 2008). Sehingga pengujian ini dilakukan untuk melihat kemampuan penghambatan dari bakteri dan cendawan calon agens hayati asal tanaman karuk untuk menekan pertumbuhan dari cendawan patogen. Berikut adalah hasil pengujian yang telah dilakukan.

Hasil ini menunjukan bahwa beberapa bakteri mampu menggagu pertumbuhan cendawan patogen, terlihat pada Gambar 3. Perlakuan F8, F12, F16, RP13 ,dan RP14 terjadi malformasi hifa dari cendawan Fusarium jika dibandingkan dengan kontrolnya, hifa dari cendawan Fusarium menjadi lebih tipis dari seharusnya dan hifa menjadi abnormal. Mekanis penekanan bakteri calon agens hayati yang mungkin dilakukan terhadap Fusarium oxysporum adalah antibiosis dan menghasilkan metabolit sekunder yang dapat melisiskan hifa dari cendawan, karena bakteri ini dapat mengeluarkan senyawa yang dapat menekan pertumbuhan cendawan patogen dan membuat pertumbuhan cendawan menjadi terhambat. Hal itu sesuai dengan pendapat Agrios (2005) menghasilkan senyawa metabolit yang bersifat racun bagi cendawan patogen.

Beberapa senyawa metabolit sekunder yang dihasilkan oleh bakteri dan dilaporkan memiliki senyawa antifungi yaitu, berdasarkan penelitian Chen et al (2009), senyawa metabolit sekunder yang dihasilkan oleh Bacillus yaitu surfactin, Bacillomycin, fengycin, peptida, dan ironsiderophorebacilibactin, yang mempunyai aktivitas antifungi. Senyawa Phenazine sebagai senyawa metabolit sekunder oleh bakteri Pseudomonas chlororaphis berperan sebagai antagonis dan aktivitas antifungi terhadap cendawan patogen Sclerotium sp. (Poritsanos 2005). Senyawa metabolit sekunder yang dihasilkan oleh bakteri Bulkhoderia adalah liquidhydrocarboncyclic terpene dan diidentifikasi sebagai senyawa cyclohexene 1-methyl-4(1-methylethenyl) dan juga senyawa 4-flavanone (4H-1Benzopyrian-4-one, 2, 3-dihydro-2-phenyl). 

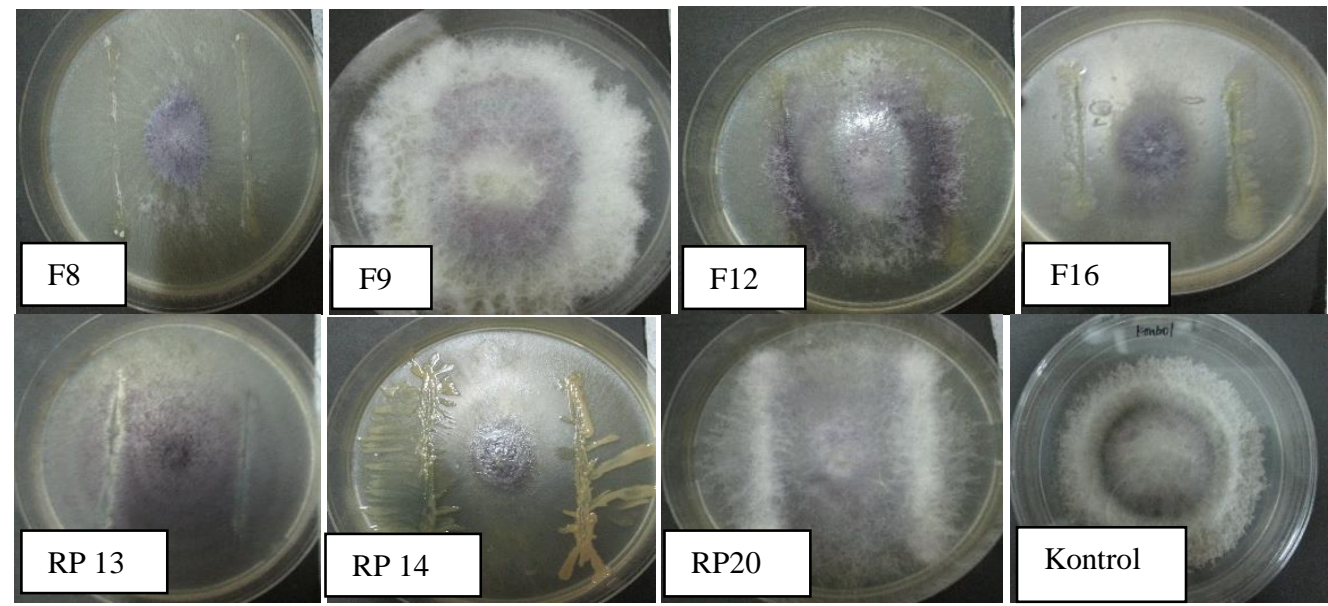

Gambar 3. Hasil pengujian agens hayati terhadap cendawan Fusariumoxysporum

\section{Kesimpulan}

Hasil penelitian ini diperoleh isolat bakteri sebanyak 73 isolat. Berdasarkan Hasil pengujian keamanan hayati hemolisis agar darah diperoleh 15 isolat bakteri yang dapat dilanjutkan ke pengujian berikutnya. Hasil pengujian hipersensitif menunjukan terdapat 7 isolat bakteri yang dapat dilanjutkan ke pengujian pertumbuhan dan dual kultur Hasil pengujian antagonis antara bakteri dan Fusarium oxysporum menunjukan bahwa beberapa bakteri mampu memperlambat pertumbuhan cendawan patogen. Hasil pengujian pertumbuhan pada benih padi dengan perlakuan FP8 menunjukkan nilai tinggi tanaman yang tertinggi jika dibandingkan dengan perlakuan lain yaitu sebesar $13.48 \mathrm{~cm}$ dan yang terrendah adalah perlakuan kontrolnya dengan $9.1 \mathrm{~cm}$. sementara untuk panjang akar perlakuan FP 16 memiliki nilai tertinggi yaitu 8.7 $\mathrm{cm}$ dan panjang akar terendah dimiliki oleh perlakuan kontrol air dengan $6.32 \mathrm{~cm}$.

\section{Ucapan Terimakasih}

Penulis mengucapkan terimaksih pada seluruh anggota laboratorium Nematologi Tumbuhan IPB yang telah berpartisipasi membantu terselenggaranya penelitian ini.

\section{Daftar Pustaka}

Agrios G. 2005. Plant Pathology. 5th eds. New York: Academic Press.

Andrews JH. 1992. Biological control in the phyllosphere. Annual review of phytopathology 30(1):603-635.
American Type Culture Collection. 2015 Introduction to Microbiology.(On-line).

https://www.atcc.org/resources/cultureguides/introduction-to-microbiology (Diakses 2 November 2021)

Blakeman JP, Fokkema N. 1982. Potential for biological control of plant diseases on the phylloplane. Annual Review of Phytopathology 20(1):167190.

Chen Y. 2008. The Unsung Heroes of the rice field. Rice today January-March 2008. IRRI. P 3031.

Duncan S, Louis P, Flint H. 2007. Cultivable bacterial diversity from the human colon. Lett Appl Microbiol. 44(4):343-350. DOI: https://doi.org/10.1111/j.1472765X.2007.02129.x

Duangpaeng A, Phetcharat P, Chanthapho S, Boonkantong N, Okuda N. 2012. The study and development of endophytic bacteria for enhancing organic rice growth. Procedia Engineering. 32(2012):172-176.

Hallmann J, Quadt-Hallmann A, Mahaffee W, Kloepper J. 1997. Bacterial endophytes in agricultural crops. Canadian Journal of Microbiology 43(10):895-914.

Kartawinata K. 2010. Dua abad mengungkap kekayaan flora dan ekosistem Indonesia. Sarwono Prawirohardjo Memorial Lecture X, LIPI 23 Agustus 2010 Jakarta. 38

Klement Z, Rudolph K, Sands D. 1990. Methods in phytobacteriology. Hungatria(HU):Akademiai Kiado.

Khusnan, Salasia SIO, Soegiyono. 2008. Isolation And Phenotipical Characterization Of Staphylococcus Aureus Isolated From 
Slaughtered House Waste And Carcass Of Chicken. Jurnal Veteriner 9(1).

Kishore, GK, S Pande, and AR Podile. 2005. Phylloplane bacteria increase seedlingemergence, growth and yield of fieldgrowngroundnut (Aracblls iznoogaea L). Letters inApplied Microbiology. 40; 260268. '

Kusmana C, Hikmat A. 2015. Keanekaragaman hayati flora di Indonesia. Jurnal Pengelolaan Sumberdaya Alam dan Lingkungan, $5(2): 187-198$

Lopez BR, Tinoco-Ojanguren C, Bacilio M, Mendoza A, Bashan Y. 2012. Endophytic bacteria of the rock-dwelling cactus Mammillaria fraileana affect plant growth and mobilization of elements from rocks. Environmental and Experimental Botany 81(2012):26-36.

Nataliya V, Balashova, Juan A, Crosby, Lourdes Al Ghofaily, Scott C. 2006. Leukotoxin confers beta-hemolytic activity to Actinobacillus actinomycetemcomitans. Infect Immun. 74(4):2015-2021. DOI: https://doi.org/10.1128/IAI.74.4.20152021.2006

Oktavia Salasia S, Khusnan Z, Lammler C, Zschock M. 2004. Comparative studies on phenol-and genotypic properties of Staphylococcus aureus isolated from bovine subclinical mastitis in central Java in Indinesia and Hesse in Germany. J Vet Sci 5(2):103-109.
Petrini O, Sieber TN, Toti L, Viret O. 1993. Ecology, metabolite production, and substrate utilization in endophytic fungi. Natural toxins 1(3):185-196.

Poritsanos NJ. 2005. Molecular Mechanisms Involved in Secondary Matabolite Production and Biocontrol of Pseudomonas chlorophis PA23. [Thesis]. Canada

(CA). The University of Manitoba.Soesanto L. 2008. Pengantar pengendalian hayati penyakit tanaman. Jakarta (ID), Rajawali Pers.

Vrbničanin S, Božić D, Sarić M, Pavlović D, Raičević V. 2011. Effect of plant growth promoting rhizobacteria on Ambrosia rtemisiifolia L. seed germination. Pesticidi $i$ fitomedicina 26(2):141-146.

Wahyudi AT, Astuti RI, Giyanto (2011). Screening of Pseudomonas sp isolated from rhizosphere of soybean plant as plant growth promoter and biocontrol agent. Am. J. Agric. Biol. Sci. (Inpress)

Whipps JM. 2001. Microbial interactions and biocontrol in the rhizosphere. Journal of experimental Botany 52(suppl 1):487-511.

Yulia E, Fitri, Ramadan FA. 2008 Kemampuan Ekstrak dan Bakteri Inhabitan Mucuna pruriens Linn. dalam Menekan Penyakit Bercak Daun Cercospora clan Meningkatkan Pertumbuhan Tanaman Kacang Tanah. J Agrikultura.1(19): 50-59. 